tion (my own of course included), so that we may still consider the instrumental investigation of earthquakes far from a settled matter, and one to be more fully worked out.

Naples, Novémber 10

H. J. Johnston-Lavis

\section{Autumn Flowering}

REFERRING to your article on autumn flowering (p. 13), I may mention that my garden primroses are now flowering again, and a laburnum is in flower in the garden of one of the houses on this road. I was in Paris in September 186I, and saw many horse-chestnuts in flower. The summer of I86I was unusually warm and dry on the Continent, though I believe not in the British Islands.

2, Osborne Park, Belfast, November I4

\section{The Northernmost Extremity of Europe}

"A Norwegian" (Nature, p. I7) says that my description of Knivskjærodden as a low glaciated tongue of rock is hardly correct. As Norwegians ought to, and generally do, know more about their own land than do foreigners, I will quote Tönsberg, whose "Norge" is admitted as a high authority by all. Describing the scene displayed from the edge of the precipice of the North Cape, he says: "Beneath you at a distance of one-eighth of a mile, you see the long low Knivskjolodde, which is undeniably the most northern part of Norway." The picture in his book (from a photograph) shows the northward extremity of this projection as washed over by the waves and its zestern side precipitous, as I saw it.

I sailed round it twice, more than ten years ago, halting in front of the North Cape for half an hour, and can only smile at the attempt to claim the northward supremacy of Knivskjærodden as a new discovery or one demanding further verification. In my copy of Munch's map (1852) it is shown as projecting a little further north than the North Cape.

Tönsberg further confirms my statement concerning the elevation of the neighbouring Arctic headlands, which "A Norwegian" also contradicts. Sverho!tklubben, according to Tönsberg, is twenty-four Norsk feet higher than the North Cape. I should have added that the measurement I gave was in Norsk feet. Measured in English feet, the height of the North Cape is 1004 feet; that of Sverholtklubben 1029 feet at the edge of the cliff. There are about a dozen other headlands of similar magnitude between North Cape and the Varangerfjord.

W. Mattieu Williams

\section{Breeding of the Quadrumana}

HAVE any of your readers any experience of the production in captivity, of a second generation of any of the quadrumana? At least twelve out of about eighty species kept in the Zoological Gardens have bred during the past thirty years-the lemurs forming a large proportion-and the Rhesus more frequently than any other monkey. I presume that even a first generation of any of the anthropoids is unknown-except possibly of the gibbon (?). The disposition and moral character (in the widest sense) of no species of monkey whatever approaches that of the dog. May not this be due to the absence of inheritance (to which the dog owes so much) of the gradually accumulate cultivation of these qualities through association with man? The dog has enjoyed all these advantages. 'The monkey can not, owing to the impossibility of rearing a succession of generations in captivity. Does the experience of your readers, who may have studied a fi:st generation of monkeys, point to any improvement on the parent stock in dis osition and character ? So far as I have been able to judge from individuals in public collections, the mere mental power of these animals con picuously exceeds that of any others. I should be glad to know whether this opinion is shared by those who have had more extended opportunities of observation.

ARTHUR NICOLS

\section{Fly-Maggots Feeding on Caterpillars}

Your correspondent, Dr. E. Bonavia (p. 29), is mistaken in supposing the flies bred from his butterfly-chrysalis were " houseflies." They belong to the sub-family Tachinina, which is of very large extent, comprising several hundreds of species in Europe alone, and all probably parasitic in other insects. The "house-fly" belongs to the sub-family Muscina. The mistake is very pardonable, for there is often great external similarity in form, colour, and size, and it is one frequently made in this country.

Clarendon Road, Lewisham, S.E., November 14

R. MCLACHLAN

IT might interest Dr. E. Bonavia (November I3, p. 29) to know that it is not an unusual circumstance to find the larvæ of the house-fly in the nests of Vespa vulgaris and $V$. germanica feeding upon the live bodies of the larvæ and pupæe of the wasps. Occasionally I have found nests in the summer-time quite deserted by the wasps, all the pupæ in the cells having been eaten by the maggots of house-flies and other Diptera.

Buckhurst Hill, Essex, November is

F. W. ElliotT

\section{The Sunday Question}

THE announcement that, "after opening the Free Library on Sundays for two months, the Town Council have resolved to close it again in consequence of the small number of visitors," seems to indicate that the Town Council of Chester were as wise in deciding to close the Library as they had previously been in giving the people of Chester an opportunity of spending a portion of their day of rest in the Public Library, where those who do not possess libraries of their own can obtain access to the wisdom of the ages as stored in books.

If the facts are as stated, no one can complain of the action of the Chester Town Council, though some would have been glad to have seen a little more patience with people who for so long have been compelled to spend their Sundays when not at home either in the church, the public-house, or the streets, all of which may be attended with advantage and profit by free and intelligent men and women; but when men are driven to either of these places, what should be a blessing becomes in too many cases a curse.

However, as I have said, we have no right to complain of the Town Council of Chester closing the Public Library on Sunday if there is no considerable number of the people of the town desirous of using the institution on that day. In civilised communities representative authorities such as town councils and parliaments are only justificd in spending public money on institutions when at lcast a considcrable section of the community desires it.

The Sunday Society bases its claim for the Sunday opening of the British Museum, the South Kensington Museum, the Natural History Museum, the National Gallery, and the Bethnal Green Museum on the ascertained fact that very large sections of the community do desire to visit them on Sundays, and if it be replied that there are more people who have no such desire and therefore these institutions should be closed, I answer that that argument would close the whole of them on every day in the week, for no one will for a moment contend that a majority of the people of the United Kingdom have visited, or can possibly visit, these national exhibitions of the wonders of the universe and what we call its highest product-man.

But the benefit of these institutions is not confined to those who actually visit them. The sermon of the Puritan divine and the lecture at the mechanic's institute are alike indebted to the British Museum and the other institutions named.

Let the trustees of the British Museum follow the example of the Town Council of Che ter and open the Museum on Sundays for two months, and the question, so far as the Sunday Society is concerned, will be settled for ever. I will venture to say that after such an experiment the British Museum would never again be closed on Sundays, and with such an example in the centre of the metropolis, no Sunday Society would be longer needed to advocate the opening of museums, art galleries, libraries, and gardens on Sundays.

The statement that at Keswick the "Sunday-opening experiment had been tried and abandoned" is true, but it should be explained that the Library at Keswick is not a public institution in the sense of bcing supported by rates and taxes, and is under the sole control of the vicar of the parish. It was the late vicar who closed the Library on Sundays, and I have the pleasure of announcing the fact that the Sunday-closing experiment has been tried and abandoned. The present vicar, the Rev. J. N. Hoare, did not decide to do this on his own authority, but he convened a special meeting of the Committee to consider the question, 